\title{
PERBANDINGAN HASIL PRODUKSI JERUK MANIS (Citrus sinensis osbec) DENGAN MENGGUNAKAN PUPUK TUNGGAL (UREA) DAN PUPUK KOMPOS DIDESA SIHEPENG
}

\author{
Eka Nurwani Ritonga ${ }^{1 *)}$, Erti Kumala Indah Nasution ${ }^{2 *}$ ) \\ Email: eka@um-tapsel.ac.id \\ ${ }^{1,2 *}$ Fakultas Pertanian Universitas Muhammadiyah Tapanuli Selatan, Sumatera Utara
}

\begin{abstract}
ABSTRAK
Tujuan dari penelitian ini adalah untuk mengetahui perbandingan hasil produksi jeruk manis (Citrus sinensis osbec)dengan menggunakan pupuk tunggal (Urea) dan pupuk kompos didesa Sihepeng. penelitian ini menggunakan rancangan acak kelompok dengan dua faktor perlakuan dan tiga ulangan, faktor merupakan hasil produksi jeruk manis (Citrus sinensis osbec) dengan menggunakan pupuk tunggal (Urea) dan pupuk kompos. Hasil Penelitian menunjukkan bahwa pemberian pupuk tunggal (Urea) berpengaruh nyata pada jumlah buah per tanaman sampel, berat buah per tanaman, jumlah buah per plot, berat buah per plot pada saat panen dan besar buah pada pasca panen. Hasil uji duncan's menunjukkan pertumbuhan tanaman yang lebih baik dengan perlakuan terbaik adalah $\mathrm{T}^{2}$ yaitu pupuk urea 125 gr. Keragaman pengamatan dari semua karakter menunjukkan kriteria pada jumlah buah pertanaman sampel, berat buah pertanaman sampel per plot, berat buah per plot.
\end{abstract}

Kata kunci : Pupuk Tunggal, Pupuk Komos, Jeruk Manis

\section{PENDAHULUAN}

Jeruk manis merupakan salah satu jenis buah-buahan yang paling digemari oleh masyarakat kita. Tanaman jeruk manis (Citrus sinensis o) juga merupakan merupakan salah satu komoditi buah-buahan yang mempunyai peranan penting dipasaran negeri maupun di pasaran dunia, baik dalam segar maupun olahan. (aak, 2011)

Tanaman jeruk merupakan komoditas buah-buahan yang termasuk kedalam jenis tanaman hortikultura yang sangat dibutuhkan oleh manusia untuk kebutuhan gizi yang seimbang sebagai sumber vitamin, mineral, dan protein. (Fiana, 2015) 
Tanaman Jeruk manis berasal dari india timur laut, cina selatan. Jeruk manis sudah tumbuh di indonesia baik secara alami atau dibudidayakan, tanaman jeruk manis yang berada diindonesia adalah tanaman jeruk peninggalan orang belanda. (Kabumaini, 2008)

Untuk memenuhi permintaan akan buah jeruk manis segar, diperlukan pertubuhan yang bagus dan baik, dengan pemberian nutrisi dan zat pengatur tumbuh, untuk mengubah proses fisiologi tumbuhan. (Wiratri, 2005). Zat-zat yang dibutuhkan oleh tanaman jeruk sangat banyak, termasuk didalamnya unsur-unsur untuk meningkatkan hasil panen. Pupuk kompos maupun pupuk anorganik sangatdiperlukan oleh tanaman, seperti pupuk tunggal urea dan pupuk kompos. Pemberian pupuk secara berimbang akan dapat mendorong pertumbuhan dan hasil panen tanaman.

Pupuk urea merupakan salah satu jenis pupuk mengandung kadar nitrogen yang sangat tinggi. Kandungan Unsur nitrogen yang terdapat didalam urea merupakan salah satu dari tiga unsur makro yang dibutuhkan tanaman. Oleh karena kandungan pupuk urea dan fungsinya maka pupuk ini sangat populer digunakan para petani baik itu petani palawija maupun petani perkebunan.

Pupuk buatan jenis urea dengan rumus kimia NH2 CONH2 ini merupakan salah satu jenis pupuk tunggal. Meskipun disebut sebagai pupuk tunggal tidak berarti kandungan yang ada didalam pupuk urea hanya memiliki 1 jenis kandungan unsur hara saja. Didalam satu karung pupuk urea terdapat beberapa jenis kandungan unsur seperti :

1. Unsur nitrogen $(\mathrm{N})$ sebanyak $46 \%$

2. Kandungan Moisture sebanyak 0.5\%

3. Kadar Biuret sebanyak 1\%

Sebagaimana diketahui bahwa manfaat unsur hara nitrogen sangat penting untuk tanaman. Unsur hara nitrogen berperan penting dalam pertumbuhan tanaman. Kandungan nitrogen yang tinggi didalam urea sangat berfungsi untuk membantu perkembangan tanaman terutama tanaman yang masih berumur muda. Tanaman muda sangat memerlukan banyak unsur hara 
nitrogen dibandingkan tanaman tua. Berikut beberapa peranan dan manfaat penting kandungan nitrogen dari pupuk urea.

1. Kandungan hara nitrogen didalam urea membuat daun tanaman lebih hijau yang bermanfaat untuk proses fotosintesa.

2. Dengan sempurnanya proses fotosintesa maka secara otomatis pertumbuhan tanaman seperti tinggi, cabang, jumlah anakan lebih cepat perkembangannya.

3. Kandungan pupuk urea yang berupa nitrogen serta kandungan lainnya dapat menjadi tambahan kandungan protein untuk tanaman.

4. Oleh karena nitrogen sangat dibutuhkan tanaman maka pupuk kimia urea ini bermanfaat untuk semua jenis tanaman.

Kesuburan tanah secara alami bergantung pada unsur-unsur kimia yang tersedia di alam. Unsur-unsur kimia alami yang terangkai menjadi bahan organik merupakan bahan penting dalam membantu menciptakan kesuburan tanah.

Bahan organik tanah memiliki banyak kegunaan, di antaranya mempertahankan struktur tanah, meningkatkan kemampuan tanah untuk menyimpan dan mendistribusikan air dan udara di dalam tanah, serta memberikan nutrisi untuk pertumbuhan tanaman dan organisme di dalam tanah.

Bahan organik yang ditransformasi menjadi pupuk sangat berperan untuk perbaikan sifat fisik dan kimia tanah. Pengaruhnya bagi sifat fisik tanah ditunjukkan dengan kemampuannya dalam merangsang granulasi, menurunkan plastisitas dan kohesi, serta meningkatkan kemampuan menahan air. Pada sifat kimia tanah, peran bahan organik adalah mem- bantu menyediakan unsur hara seperti nitrogen, fosfor, belerang, dan kation.

Tujuan penelitian ini untuk mengetahui perbandingan hasil produksi jeruk manis (Citrus sinensis obseck) dengan menggunakan puopuk tunggal urea dengan pupuk kompos didesa sihepeng. 


\section{BAHAN DAN METODE PENELITIAN}

Penelitian ini dilakukukan pada bulan Oktober sampai Desember 2015 di desa Sihepeng Kecamatan Siabu Kabupaten Mandailing Natal.

Penelitian ini dilakukan dengan menggunakan rancangan acak kelompok (RAK) non faktorial dengan dua faktor yaitu: a. Faktor pupuk tunggal disimbolkan (T) terdiri dari tiga taraf yaitu $\mathrm{T}^{\circ}$ tanpa perlakuan, $\mathrm{T}^{1}$ (100 gr r), $\mathrm{T}^{2}$ (125) gr, $\mathrm{T}^{3}$ (150 gr). B. Faktor pemberian pupuk kompos dengan 4 taraf : $\mathrm{K}^{\circ}$ (tanpa perlakuan), $\mathrm{K}^{1}$ (250 gr/pohon), $\mathrm{K}^{2}$ (350 gr/pohon ), K (450 gr/pohon) Model yang digunakan dalam rancangan ini adalah model linier (Ali Hanafiah 2010). model linear ini adalah sebagai berikut :

Yijk: $\mu+\rho \mathbf{i}+\alpha \mathbf{j}+\beta \mathbf{k}+(\alpha \beta) \mathbf{j k}+\Sigma \mathbf{i j k}$

Yijk : Hasil pengamatan faktor t pada taraf ke-i dan faktor r pada taraf ke-k dalam ulangan ke-I

$\mu \quad$ : Efek dari nilai tengah

рi : Efek dari blok pada taraf ke-I

$\alpha \mathrm{j} \quad$ : Efek dari faktor A pada taraf ke-j

$\beta \mathrm{k} \quad$ : Efek dari faktor J pada taraf ke-k

$(\alpha \beta)$ : Efek dari interaksi faktor t pada taraf ke-j dan faktor $r$ pada taraf ke-k

¿ijk : Efek eror dari faktor t pada taraf ke-j dan faktor r pada taraf ke-k serta dalam ulangan ke-I (gomez,1996)

\section{PELAKSANAAN PENELITIAN}

Areal yang akan digunakan terlebih dahulu dibersaihkan dari gulma. Pembersihan lahan dilakukan dengan membersihkan lahan dari semak dan gulma yang ada pada lahan, dilakukan secara mekanis ataupun kimiawi. Kemudian hasilnya dikumpulkan dan dibakar. Pembuatan plot dengan model persegi petak dengan ukuran 4mx4m dengan arah utara dan selatan. Jumlah buah dalam satu petak 4 buah dengan 3 buah tanaman sampel. Plot yang dibuat 
dengan tiga ulangan. Parameter pengamatan pada penelitian ini adalah jumlah buah pertanaman sampel, berat buah pertanaman, berat buah per plot.

\section{HASIL}

Berdasarkan hasil analisis sidik ragam pengamatan terhadap jumlah buah per tanaman sampel, berat buah pertanaman dan berat buah per plot dapat dilihat pada tabel berikut :

Tabel 1. Rataan jumlah buah per tanaman sampel jeruk, perlakuan pupuk tunggal (urea) pada panen dan pasca panen.

\begin{tabular}{lcc}
\hline Pupuk Tunggal (Urea) & \multicolumn{2}{c}{ Jumlah Buah Per Tanaman Sampel } \\
\cline { 2 - 3 } & Panen & Pasca Panen \\
\hline $\mathrm{T}^{\circ}$ & $202,77 \mathrm{Ab}$ & $118,17 \mathrm{ab}$ \\
$\mathrm{T}^{1}$ & $194,49 \mathrm{ab}$ & $113,09 \mathrm{a}$ \\
$\mathrm{T}^{2}$ & $233,47 \mathrm{bc}$ & $138,76 \mathrm{ab}$ \\
$\mathrm{T}^{3}$ & $192,63 \mathrm{a}$ & $119,67 \mathrm{ab}$ \\
\hline
\end{tabular}

Keterangan : Angka yang diikuti huruf yang sama pada kolom dan baris menunjukkan tidak berbeda nyata menurut Uji DMRT 5 \%

Tabel 2. Rataan jumlah buah pertanaman sampel jeruk perlakuan pupuk kompos pada panen dan pasca panen

\begin{tabular}{lcc}
\hline Pupuk kompos & \multicolumn{2}{c}{ Jumlah Buah Per Tanaman Sampel } \\
\cline { 2 - 3 } & Panen & Pasca Panen \\
\hline $\mathrm{K}^{\circ}$ & $201,02 \mathrm{~A}$ & $110,09 \mathrm{a}$ \\
$\mathrm{K}^{1}$ & $202,27 \mathrm{ab}$ & $121,75 \mathrm{ab}$ \\
$\mathrm{K}^{2}$ & $205,23 \mathrm{ab}$ & $127,85 \mathrm{ab}$ \\
$\mathrm{K}^{3}$ & $214,85 \mathrm{ab}$ & $130,00 \mathrm{ab}$ \\
\hline
\end{tabular}

Keterangan : Angka yang diikuti huruf yang sama pada kolom dan baris menunjukkan tidak berbeda nyata menurut Uji DMRT 5 \%

Tabel 3. Hasil interaksi pengaruh pupuk tunggal (urea) dan pemberian pupuk kompos terhadap jumlah buah per tanaman sampel jeruk pada pasca panen.

\begin{tabular}{lccccc}
\hline Perlakuan & $\mathrm{K}^{\circ}$ & $\mathrm{K}^{1}$ & $\mathrm{~K}^{2}$ & $\mathrm{~K}^{3}$ & Rataan \\
\hline $\mathrm{T}^{\circ}$ & 103,40 & 110,50 & 124,83 & 133,93 & $118,17 \mathrm{ab}$ \\
$\mathrm{T}^{1}$ & 105,17 & 117,07 & 111,50 & 118,63 & $113,09 \mathrm{a}$ \\
$\mathrm{T}^{2}$ & 120,40 & 140,60 & 155,20 & 138,83 & $138,76 \mathrm{ab}$ \\
$\mathrm{T}^{3}$ & 111,40 & 118,83 & 119,87 & 128,60 & $119,68 \mathrm{ab}$ \\
\hline Rataan & $110,09 \mathrm{a}$ & $121,75 \mathrm{ab}$ & 127,85 & 130,00 & $122,42 \mathrm{ab}$ \\
\hline
\end{tabular}


Berdasarkan tabel diatas terlihat bahwa interaksi pengaruh pupuk tunggal (urea) dan pemberian pupuk kompos terhadap jumlah buah per tanaman, sampel jeruk pada panen dan pasca panen. Berdasarkan tabel diatas terlihat bahwa pengamatan tertinggi terdapat pada perlakuan $T^{2} K^{2}(155,20)$ dan pengamatan terendah $T^{0} K^{0}(103,40)$. Adanya pengeruh tidak nyata disebabkan oleh kedua faktor perlakuan tersebut tidak bereaksi secara bersamaan sehingga interaksi tidak berpengaruh secara nyata dan untuk faktor lainya adalah faktor genetik dan faktor lingkungan, dikarenakan kelembapan tanah dan ph tanah pada lahan percobaan terlalu lembab dikarenakan iklim dan cuaca pada saat penelitian tidak mendukung oleh sebab itu penyerapan unsur-unsur yang terkandung didalam pupuk tunggal (urea) dan pupuk kompos tidak dapat menyerap secara secara ideal.

\section{KESIMPULAN}

Dari hasil penelitian perbandingan hasil produksi jeruk manis (citrus sinensis osbeck) dengan menggunakan pupuk tunggal (urea) dan pupuk kompos didesa sihepeng, menunjukkan pengaruh yang tidak nyata. Hal ini dikarenakan pengararuh lingkungan yang tidak mrndukung pada saat penelitian.

\section{DAFTAR PUSTAKA}

Aak. 1994. Budidaya tanaman jeruk. Yogyakarta : Kanisius

Novizan. 2005. Petunjuk pemupukan yang efektif. Jakarta : Graha ilmu

Gomez dan A.A Gomez, 2007. Prosedur statistik untuk penelitian pertanian edisi ke 2

Rambe, et.al. 2014. Pengaruh pemupukan dan pemangkasan terhadap kualitas buah jeruk gerga lebong 1 (penyuluh pertanian madya, BPTP bengkulu2) calon peneliti BPTP bengkulu

Kabumaini Nasir, S. Ranuatmaja Tjetjep. 2008. Bertanam jeruk. Bandung : PT. Puri delco 